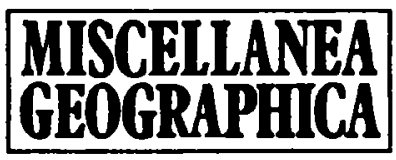

WARSZAWA 1994 Vol. 6

Mirosław Bogacki

\title{
CONTEMPORARY LANDSCAPE DEVELOPMENT PROCESSES AS AN INDICATOR OF ANTHROPOPRESSURE
}

The present state of landscape evolution can be studied as a causality, characteristic on the one hand of the chemical system, and on the other of the physical system of landscape modelling. Man's activity modifies the natural processes characteristic for the systems.

The most visible transformations of the landscape occur in urbanized and industrialized areas since the forms existing there are usually man's creation. In agricultural areas, primarily in large estates, frequently there are also irreversible changes in landscape.

Man's indirect influence on contemporary changes in the landscape is more complex and often poorly studied. This in particular refers to chemical denudation. Within the system of chemical denudation, there is a soil subsystem represented by leaching (acidifying) processes and a rock subsystem, represented by karstic phenomena.

The system of chemical landscape modelling is modified by man who makes changes in the range and character of natural vegetation, and thus the features of local climate and soil moisture, by using artificial fertilizers, particularly mineral ones, physiologically acidic, plant protection chemicals and various chemical compounds emitted by industry. Emission of sulphur and nitrogen compounds is particularly dangerous; by the year 2000 the emission of sulphur will grow by $225 \%$ in relation to 1980 .

Man's interference in the system of chemical landscape modelling produces less alkali compounds in the soil and an excessive acidifying. The process is particularly intensive in agricultural areas (Contemporary changes... 1990). Only locally there are trends towards alkalization of soil.

The process of acidifying produces a poorer fertility and lesser fecundity of the soil. The areas of very acid and acid soils in Poland are estimated at $70 \%$ of arable land. It is estimated that the losses of calcium compounds in Poland amount to $250-300 \mathrm{~kg} / \mathrm{ha}$. The losses are not compensated for with fertilizers since on the average it is $135 \mathrm{~kg} \mathrm{CaO} / \mathrm{ha}$ in Poland and in some provinces it is below the average, e.g. in the province of Siedlce it is 34.0 $\mathrm{km} / \mathrm{ha}$ and in Bielsko-Biała - $35.7 \mathrm{~kg} / \mathrm{ha}$. 
The quantity of chemical solutions discharged from the Vistula basin in the second half of the 1970 s was $50 \mathrm{t} / \mathrm{km}^{2} /$ year (Contemporary changes... 1990). The volume was highly differentiated by regions, ranging from over $100 \mathrm{t} / \mathrm{km}^{2} /$ year in the mountains to about $30 \mathrm{t} / \mathrm{km}^{2} /$ year on the lowlands of central Poland. Maruszczak's calculations (Contemporary changes... 1990) show that the discharged chemical compounds had various origins.

If the amount of $50 \mathrm{t} / \mathrm{km}^{2} /$ year is accepted as $100 \%$, it was composed of compounds supplied with precipitation $-8 \mathrm{t} / \mathrm{km}^{2} /$ year $(16 \%)$, solutions related to chemistry in agriculture $-6.5 \mathrm{t} / \mathrm{km}^{2} /$ year (13\%), substances artificially supplied with liquid sewage $-6 \mathrm{t} / \mathrm{km}^{2} /$ year (12\%), natural substances from sewage $-5.5 \mathrm{t} / \mathrm{km}^{2} /$ year $(11 \%)$ and finally substances from natural chemical denudation of the lithosphere $-24 \mathrm{t} / \mathrm{km}^{2} /$ year (48\%).

The above data show the volume of economic losses suffered by the economy: washing out of artificial fertilizers, discharge of various substances produced by industry and finally an adverse impact of polluted rivers on the flora and fauna of rivers and lakes.

As a result of man's interference, significant changes also occur in the system of physical modelling of the earth's surface. They concern both the subsystem of summits and slopes as well as the subsystem of river valley bottoms.

In connection with deforestation and introduction of new systems of farming, three to four periods of intensified denudation can be distinguished within the last five hundred years (Strzemski 1964). The first period is between the 15th and 17th centuries and is connected with the introduction of a farm and villein system. Particularly intensive denudation occurred in the Lublin and Little Poland Uplands and some areas of the Carpathian Plateau. The second period was between 1864 and 1880 and is related to a reconstruction of rural farming in the former Russian territory of partitioned Poland after the peasants were enfranchised. About 25\% of forests were cleared during that time. Most intensive denudation processes occurred in the Lublin and Little Poland Uplands. The third period is related to the land reform after World War II (1945-1946). At that time numerous small farms were formed, which usually slows down denudation processes. No significant forest clearing took place at the time, either. However, the processes of denudation during that period were stimulated by the destruction of preserves for hares and game fowl, liquidation of natural fallow land in some areas and turning green pastures in dry areas into arable land. Finally, the fourth period of intensified denudation is related to the development of State Farms and farm collectivization. The development of morphological processes was favoured by liquidation of balks, trees and mechanization of farming in large areas along slopes. At present in some regions of Poland, arable land covers $80-90 \%$ of the area. Crops provide much less protection than forests or pastures (Contemporary changes... 1990).

The soil denudation index in mm/year, calculated by E. Gil (1976) for Be- 
skid slopes is 0.00003 on slopes covered with forest, 0.0012 on pastures, 0.028 on meadows, 0.0043 on slopes with grain crops and 2.97 with root crops.

The situation of small farms has produced a new morphodynamic regime expressed in lesser intensification of denudation processes on slopes, excluding roads among fields and increased erosion in river beds.

A similar effect was produced in the period 1950-1970 in effect of new afforestation in some parts of the Beskid Mountains. When farming was stopped or slowed down, the developing forest changed water circulation and limited the supply of weathered material from slopes to river beds.

At present, field roads, cutting into valley slopes (Froehlich 1982) play a very important role in the process of transportation of washed soil in agriculturally used areas. The roads are main supply lines of material to brooks and rivers.

In the areas of loess uplands characterized by very small fields, apart from an intensive soil washing, related to the type and manner of farming, the impact of anthropopressure is manifested in creation of various forms of road ravines. In the Lublin Upland, road ravines constitute $40 \%$ of the total length of ravines. Increased accumulation in river valley bottoms is also an effect of slopes degradation.

Deforestation and changes in farming also influence the process of natural evolution of river valley bottoms (Contemporary changes... 1990), produce stronger flood waves and increased volume of material taken away. This produced a change of the character of many parts of rivers from meandering to brooks. Regulation of lower parts of river-beds as well as division of farm land into smaller plots and afforestation resulted in the last 30-40 years in the deepening of Carpathian river beds by about 10 $\mathrm{cm} /$ year (Starkel 1976). Despite a substantial material supply from slopes and tributaries, mountain river beds are getting deeper both in its mountain part (return to a trend from before deforestation) as well as in lower parts which is an intensification of contrast in relation to natural trends. According to $\mathrm{K}$. Klimek (1983) the present rate of the deepening of Carpathian river beds is several dozen times faster than in the few previous millennia and two to four times faster than 25 years ago.

Anthropopressure-related erosion trends in rivers are also visible at the foot of the Carpathians. The trends gradually diminish along with growing distance from the mountains and in the northern part of the Sandomierz Basin they are hardly noticeable. In the period 1965-1975, the volume of erosion of some rivers in the Sandomierz Basin was 0.5 to $9 \mathrm{~cm} /$ year. Further northwards river valleys change their morphogenetic features and accumulation starts to prevail, also much influenced by man's activity. In the Vistula valley, sedementation is the largest between Zawichost and Pulawy, averaging 670 thousands tons of rubble annually (Brański 1975). The Bug manifests similar features where accumulation reaches 17 thousand tons annually. 
Changes in natural morphogenetic trends are at present visible in valley bottoms and they reflect both man's activity in the basin as well as his direct impact on river beds. Large reservoirs fulfill a specific morphogenetic role as they detain substantial quantities of dragged and floating material as well as material supplied from slopes due to surface washing and abrasion. They also have an impact on increased agradation above the reservoir and development of degradation trends below the dams.

The process of abrasion of banks of artificial water reservoirs which is entirely due to anthropopressure is worthy of attention.

Exploitation of natural aggregate has a significant impact on the processes in river-beds. The Carpathians and their foreground are one of significant areas of deposits of gravel and sand-gravel mix. The deposits constitute about $27 \%$ of country's deposits (Rutkowski 1976).

The building aggregate exploitation makes that river-beds get much deeper, water level is lowered, terraces become drier and water intakes and other structures are destroyed. The average deepening of the Ropa bed in Szymbark in the period 1969-1975 was $8.2 \mathrm{~cm}$ (Soja 1976).

Changes made by man in spatial structure of vegetation as well as farming activated eolithic phenomena which can become significant under favourable topographic and soil-water conditions as well as with the good weather, e.g. on the loess soil of the Lublin Upland up to 600 t/ha (Strzemski 1957) and in the Jasielsk-Sanok Hollows $50-360 \mathrm{~m}^{3} / \mathrm{ha}$ (Gerlach, Koszarski 1986).

Apart from natural mineral substances accumulated from the atmosphere, the balance of presently circulating matter also includes industrial dusts emitted from industrial plants as well as dusts from dumping grounds scattered by winds.

The morphogenetic processes presented above, that are either activated or accelerated by man, cause a visible degradation of forms of landscape and frequently cause a disfunction of the entire geosystems.

\section{REFERENCES}

Brański J., 1975, "Ocena denudacji dorzecza Wisły na podstawie wyników pomiarów rumowiska unoszonego" (An assessment of denudation in the Vistula basin on the basis of measurements of floating rubble), Pr. IMGiW 6.

Wspólczesne przemiany rzeźby Polski potudniowo-wschodniej (Present-day changes of relief in south- eastern Poland), Praca zbiorowa, 1990, Pr. Geogr. IGiPZ PAN 153.

Froe hli ch W., Mechanizmy transportu fluwialnego i dostawy zwietrzelin do koryta w górskiej zlewni fliszowej (The mechanism of fluvial transportation and supply of weathered material in the Carpathian flysh basin), Pr. Geogr. IGiPZ PAN 143.

Gerlach T., Koszarski L., "Wspólczesna rola morfogenetyczna wiatru na przedpolu Beskidu Niskiego" (The contemporary morphogenetic role of winds at the foot of the Lawer Beskid), Stud. Geomorph. Carp-Balc., vol. 2. 
Gil E., 1976, "Splukiwanie gleby na stokach fliszowych w rejonie Szymbarku" (Soil washing on flysch slopes in the vicinity of Szymbark), Dok. Geogr., 2.

Klimek K., 1983, "Erozja wgłebna dopływów Wisły na przedpolu Karpat" w: Ekologiczne podstawy zagospodarowania Wisty $i$ jej dorzecza (Subterranean erosion in the Vistula tributaries at the foot of the Carpathians. Ecological problems related to the regulation of the Vistula and its basin), PWN, Warszawa-Lódź.

Rutkowski J., 1976, "Kruszywa naturalne Karpat i ich znaczenie surowcowe", w: Wyksztatcenie mtodoczwartorzedowych aluwiów rzek karpackich $i$ ich znaczenie surowcowe, (Natural aggregates in the Carpathians and their industrial significance. Young Quaternary forms of Carpathian river alluvia and their industrial significance), Mater. Teren. Konf. Nauk., Kraków.

Soja R., 1976, "Proces pogtębiania koryta rzeki Ropy w latach 1968-1974", w: Wyksztatcenie mlodoczwartorzedowych aluwiów rzek karpackich $i$ ich znaczenie surowcowe (The deepening process of the Ropa bed in the period 1968-1974. Young Quaternary forms of Carpathian river alluvia and their industrial significance), Mater. Teren. Konf. Nauk., Kraków.

St arkel L., Przebieg erozji i akumulacji młodoczwartorzędowej w dolinach karpackich [w:] Wyksztalcenie mlodoczwartorzędowych aluwiów rzek karpackich $i$ ich znaczenie surowcowe (The process of erosian and accumulation of young Quaternary period in Carpathian valleys. Young Quaternaary forms of Carpathian river alluvia and their industrial significance), Mater. Teren. Konf. Nauk., Kraków.

Strze m ski M., "Efekty erozji wietrznej gleb na terenie południowo-wschodniej Polski w lutym 1956 roku" (Effects of soil wind erosion in south-eastern Poland in February 1956), Prz. Geogr., 29.

S t rz e m sk i M., Uwagi ogólne o przemianach środowiska geograficznego Polski jako tla przyrodniczego rozwoju rolnictwa od polowy trzeciego tysiqclecia p.n.e. do naszych czasów. Zarys historii gospodarstwa wiejskiego $w$ Polsce (General remarks on changes in Poland's geographical environment since as a natural background of agriculture development from the middle of the third millennium B.C till our times. An outline of the farming history in Poland), vol. 1., PWRiL Warszawa. 
